\title{
Anoxybacillus bogrovensis sp. nov., a novel thermophilic bacterium isolated from a hot spring in Dolni Bogrov, Bulgaria
}

Correspondence

Margarita Kambourova margikam@microbio.bas.bg

\author{
Miroslava Atanassova, ${ }^{1}$ Anna Derekova, ${ }^{1}$ Rossica Mandeva, ${ }^{1}$ \\ Carsten Sjøholm ${ }^{2}$ and Margarita Kambourova ${ }^{1}$ \\ ${ }^{1}$ Institute of Microbiology, Bulgarian Academy of Sciences, 'Acad. G. Bonchev' Str. 26, 1113 Sofia, \\ Bulgaria
}

${ }^{2}$ Novozymes, Krogshøjvej 36, 2880 Bagsværd, Denmark
The genus Anoxybacillus, with the type species $A$. pushchinoensis, was proposed and Bacillus flavothermus (Heinen et al., 1982) was reclassified as Anoxybacillus falvithermus by Pikuta et al. (2000). At present, the genus comprises 10 species with validly published names. Although representatives of the genus Anoxybacillus were identified initially as anaerobes, an additional amendment referred to them as aerotolerant anaerobes (Pikuta et al., 2003). Most of the species were found to be facultative anaerobes (Anoxybacillus voinovskiensis, A. flavithermus, A. gonensis, A. amylolyticus, A. contaminans, A. kamchatkensis) but, for some species, anaerobic growth was registered only under certain conditions (Dulger et al., 2004; Poli et al., 2006). Anoxybacillus rupiensis was described as a strict aerobe (Derekova et al., 2007). In the present study, we report on the phylogenetic, physiological and biochemical characteristics of a novel thermophilic, facultative anaerobic micro-organism with amylolytic activity, strain BT $13^{\mathrm{T}}$, which was isolated from a geothermal spring in the village of Dolni Bogrov, Sofia region, Bulgaria. The properties determined indicated that strain BT $13^{\mathrm{T}}$ represents a novel species of the genus Anoxybacillus.

The GenBank/EMBL/DDBJ accession number for the $16 \mathrm{~S}$ rRNA gene sequence of strain BT $13^{\top}$ is AM409184.
Strain BT $13^{\mathrm{T}}$ was isolated from a mud sample with a $\mathrm{pH}$ of 8.5 and a temperature of $56{ }^{\circ} \mathrm{C}$, taken from a geothermal spring near the village Dolni Bogrov, Sofia region, Bulgaria. Samples were enriched in PY medium ( $\mathrm{pH} 7.0$ ), containing $\left(1^{-1}\right): 2 \mathrm{~g}$ peptone and $1 \mathrm{~g}$ yeast extract, and plated on PY agar $(\mathrm{pH} 7.0)$. The cultures were incubated for $18 \mathrm{~h}$ at $60{ }^{\circ} \mathrm{C}$ and at 240 r.p.m. Pure strains were isolated after at least three repeated cultivations on agar. The cultures were considered to be pure when only one type of bacterium per culture was observed microscopically.

Morphological properties of strain BT $13^{\mathrm{T}}$ were determined using light and electron microscopy of ultrathin sections of cells after cultivation for $24-48 \mathrm{~h}$ on agar medium (Boone et al., 1995). The cells were typically endospore-producing, Gram-positive (Gram colour staining set; Merck), regular, non-motile rods, 1.4-4.0 $\mu \mathrm{m}$ long and $0.3-0.6 \mu \mathrm{m}$ wide (Fig. 1). A distal formation of ellipsoidal endospores was observed using electron microscopy. The novel isolate differed from its closest relatives (Table 1) with respect to its lack of motility.

Physiological and biochemical characteristics of the isolate were investigated as described by Smibert \& Krieg (1981). The fermentative properties of the novel isolate were examined using minimal salt medium, consisting of $\left(1^{-1}\right)$ : 


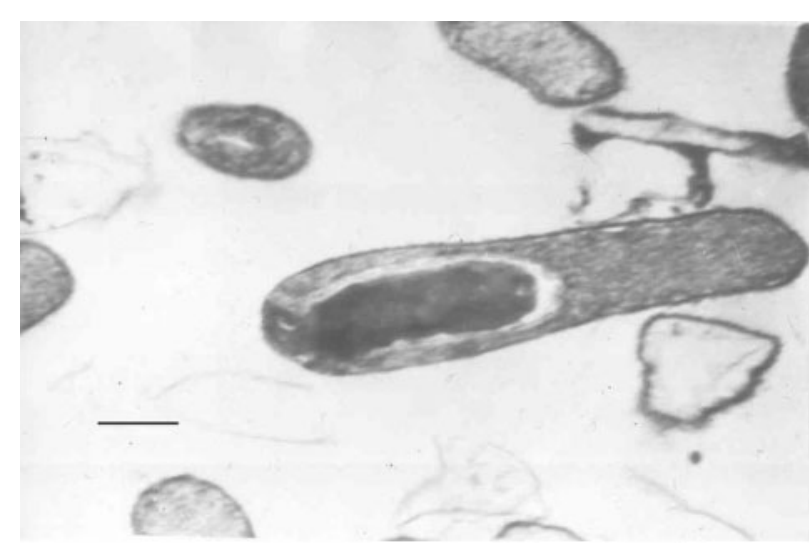

Fig. 1. Transmission electron micrograph of cells of strain $B T 13^{\top}$ (24 h cultivation) showing typical endospore formation and free spores. Bar, $0.5 \mu \mathrm{m}$.

$1 \mathrm{~g}\left(\mathrm{NH}_{4}\right)_{2} \mathrm{HPO}_{4}, 0.2 \mathrm{~g} \mathrm{KCl}, 0.1 \mathrm{~g} \mathrm{MgSO}_{4}, 1 \mu \mathrm{g}$ thiamin and $0.0001 \mathrm{~g}$ bromothymol blue, with the addition of $0.01 \%$ $(\mathrm{w} / \mathrm{v})$ yeast extract. Carbohydrates were added to a final concentration of $0.1 \%(\mathrm{w} / \mathrm{v})$. Sugars tested were D-glucose, sucrose, D-lactose, D-ribose, D-fructose, L-arabinose, Dlaevulose, D-galactose, raffinose, L-rhamnose, D-mannose, D-xylose and cellobiose. Polyols tested were inositol, ribitol, mannitol, sorbitol and galactitol. The following polysaccharides were used: dextran, glycogen, inulin, salicin and starch. Catalase activity was assayed by mixing a pellet of a freshly centrifuged culture with a drop of $6 \%$ hydrogen peroxide. Anaerobic growth was tested on PY agar at $60{ }^{\circ} \mathrm{C}$ in a jar, with Anaerocult A (Merck) as a reducing agent. Growth was also determined in tubes with PY agar slants under optimal growth conditions, and stab cultures with a paraffin film on top. Growth experiments were carried out in triplicate. Anaerobic growth was observed only when Anaerocult A was used. Other tests were performed using an API 20E kit (bioMérieux) at $55^{\circ} \mathrm{C}$, according to the manufacturer's instructions. The major physiological and biochemical properties of the novel isolate differed from those of its closest relatives (Table 1) in the spectrum of carbohydrate utilization. Strain BT $13^{\mathrm{T}}$ differed from its nearest neighbour, A. flavithermus (16S rRNA gene sequence similarity of $96.8 \%$ ) in its smaller dimensions, morerestricted temperature range for growth, alkaline $\mathrm{pH}$ values,

Table 1. Differential characteristics of strain $\mathrm{BT} 13^{\top}$ and its closest relatives, A. flavithermus, A. gonensis, A. ayderensis and $A$. kamchatkensis

Strains: 1, BT $13^{\mathrm{T}}$ (A. bogrovensis sp. nov.); 2, A. flavithermus DSM $2641^{\mathrm{T}}$ (data from Pikuta et al., 2000); 3, A. gonensis NCIMB $13933^{\mathrm{T}}$ (Belduz et al., 2003); 4, A. ayderensis NCIMB $13972^{\mathrm{T}}$ (Dulger et al., 2004); 5, A. kamchatkensis JW/VK-KG4 ${ }^{\mathrm{T}}$ (Kevbrin et al., 2005). All strains are facultative anaerobes. +, Positive; -, negative; $\mathrm{w}$, weak response; ND, not determined.

\begin{tabular}{|c|c|c|c|c|c|}
\hline Characteristic & 1 & 2 & 3 & 4 & 5 \\
\hline Source of isolation & $\begin{array}{c}\text { Geothermal water } \\
\text { (Bulgaria) }\end{array}$ & $\begin{array}{l}\text { Geothermal water } \\
\text { (India) }\end{array}$ & $\begin{array}{c}\text { Geothermal water } \\
\text { (Turkey) }\end{array}$ & $\begin{array}{c}\text { Geothermal water } \\
\text { (Turkey) }\end{array}$ & $\begin{array}{c}\text { Geothermal waters } \\
\text { (Geyser valley, } \\
\text { Russian } \\
\text { Kamchatka) }\end{array}$ \\
\hline Cell size [length/width] $(\mu \mathrm{m})$ & $1.37-4.03 \times 0.34-0.57$ & $0.85 \times 2.30-7.10$ & $0.75 \times 5.00$ & $0.55 \times 4.60$ & $2.5-8.8 \times 1.0$ \\
\hline Motility & - & + & + & + & + \\
\hline Catalase formation & + & + & $\mathrm{w}$ & + & - \\
\hline $\begin{array}{l}\text { Temperature range for growth } \\
\text { (optimum) }\left({ }^{\circ} \mathrm{C}\right)\end{array}$ & $40-69(65)$ & $30-72(60-65)$ & $40-70(55-60)$ & $30-70(50)$ & $38-67(57-62)$ \\
\hline $\begin{array}{l}\mathrm{pH} \text { range for growth } \\
\text { (optimum) }\end{array}$ & $6.5-10.0(8.0)$ & $5.5-9.0(7.0)$ & $6.0-10.0(7.5-8.0)$ & $6.0-11.0(7.5-8.5)$ & $5.7-9.9(6.8-8.5)$ \\
\hline $\mathrm{NaCl}$ range $(\%)$ & $0.5-1.5$ & $0.0-2.5$ & $0.0-4.0$ & $0.0-2.5$ & $\mathrm{ND}$ \\
\hline DNA G $+\mathrm{C}$ content $(\mathrm{mol} \%)$ & 44.1 & 42.3 & 57.0 & 54.0 & 42.3 \\
\hline Nitrate reduction & - & + & - & + & $\mathrm{ND}$ \\
\hline \multicolumn{6}{|l|}{ Substrates utilized } \\
\hline L-Arabinose & + & $\mathrm{w}$ & - & + & - \\
\hline Xylose & - & - & + & - & - \\
\hline D-Glucose & + & - & + & + & + \\
\hline D-Mannose & - & + & - & + & - \\
\hline Sucrose & + & $\mathrm{ND}$ & - & + & + \\
\hline Glycogen & + & - & + & $\mathrm{ND}$ & ND \\
\hline \multicolumn{6}{|l|}{ Hydrolysis of: } \\
\hline Gelatin & + & - & + & + & - \\
\hline Casein & - & + & ND & ND & - \\
\hline Starch & + & - & + & + & - \\
\hline
\end{tabular}


lower $\mathrm{NaCl}$ tolerance, fermentation of glucose, lack of nitrate reduction, and hydrolysis of glycogen and gelatin. The final products of amylolytic action on starch of strain BT $13^{\mathrm{T}}$ were assayed using both TLC and HPLC. The products of hydrolysis of various $\alpha$-glucans were developed using TLC Silicagel 60 precoated plates $(25 \times 25 \mathrm{~cm}$; Merck). An amylolytic activity assay (Pantschev et al., 1981; Miller, 1959) revealed that the enzyme synthesis was constitutive and was located in the cytosol. Final products of the enzyme reaction were predominantly glucose, with traces of maltose (data not shown), suggesting an exomechanism of enzyme action. Amylolytic activity has been observed for A. amylolyticus (Poli et al., 2006) and the enzyme synthesized was $\alpha$-amylase, whereas the enzyme from strain BT $13^{\mathrm{T}}$ had an exo-mechanism of action.

Partial (1-501 nt; Escherichia coli numbering) and full sequence (8-1513 nt; E. coli numbering) analysis of the $16 \mathrm{~S}$ rRNA gene of strain BT $13^{\mathrm{T}}$ was performed at Novozymes, Denmark, as described by Johansen et al. (1999). The phylogenetic tree was constructed using the Fast DNA Ml tool in the ARB program package (Strunck \& Ludwig, 1995). The results of the $16 \mathrm{~S}$ rRNA gene sequence analysis placed the novel isolate in the genus Anoxybacillus (Fig. 2). The closest phylogenetic neighbours were A. flavithermus, A. kamchatkensis and A. ayderensis (sequence similarities of 96.8, 96.8 and $96.5 \%$, respectively). Other recognized species of the genus Anoxybacillus had sequence similarities of less than $96 \%$. The significant phylogenetic distance from all these micro-organisms clearly indicated that strain BT $13^{\mathrm{T}}$ represents a separate taxon, with an evolutionary distance greater than the level (3\% distance) at which strains are attributed to separate species (Stackebrandt \& Goebel, 1994).

Extraction and purification of the genomic DNA and determination of the $\mathrm{G}+\mathrm{C}$ content for the novel isolate were performed at DSMZ (Braunschweig, Germany), using the HPLC method (Mesbah et al., 1989). The DNA G +C content of strain $\mathrm{BT} 13^{\mathrm{T}}$ was $44.1 \mathrm{~mol} \%$, in the range of values for recognized Anoxybacillus species (Table 1).

Cultivation, harvesting, preparation and analysis of cellular fatty acid methyl esters from whole-cell fatty acids were performed at DSMZ, according to the Sherlock Microbial Identification System manual (version 4.0; MIDI). The fatty acid pattern of strain BT $13^{\mathrm{T}}$ was identified by comparison with patterns stored in the MIDI database (MIS; USA) using the MIDI V. 4.0 library. The results from the fatty acid analysis revealed that strain BT $13^{\mathrm{T}}$ synthesized mainly iso- and anteiso-branched saturated fatty acids, similar to thermophilic Bacillus and Thermus species. Good correspondence with the general features of fatty acid profiles of recognized Anoxybacillus species was demonstrated, with the main fatty acids being iso- $\mathrm{C}_{15: 0}$ and iso- $\mathrm{C}_{17: 0}$. The iso-branched fatty acids comprised about $80 \%$ of the total fatty acids. The major fatty acid of strain $\mathrm{BT} 13^{\mathrm{T}}$ and the closest relatives A. ayderensis, $A$. flavithermus and A. gonensis was iso- $\mathrm{C}_{15: 0}$, followed by iso$\mathrm{C}_{17: 0}$ and anteiso- $\mathrm{C}_{17: 0}$. However, lower contents of shorter fatty acids such as $\mathrm{C}_{14: 0}(0.4 \%)$, iso- $\mathrm{C}_{14: 0}$ $(0.25 \%), \mathrm{C}_{15: 0}(0.4 \%)$, iso- $\mathrm{C}_{15: 0}(40.1 \%)$ and anteiso$\mathrm{C}_{15: 0}(1.8 \%)$ were observed. Instead, the contents of fatty acids with longer chains such as iso- $\mathrm{C}_{17: 0}(36.1 \%)$, anteiso- $\mathrm{C}_{17: 0}(8.98 \%), \mathrm{C}_{18: 0} \quad(0.5 \%)$ and iso- $\mathrm{C}_{19: 0}$ $(0.5 \%)$ were higher for strain BT $13^{\mathrm{T}}$. In addition, the contents of iso- $\mathrm{C}_{16: 0}$ and $\mathrm{C}_{16: 0}$ were determined to be 3.9 and $6.3 \%$, respectively.

On the basis of its $16 \mathrm{~S}$ rRNA gene sequence, strain BT $13^{\mathrm{T}}$ was placed within the genus Anoxybacillus. Its physiological characteristics, 16S rRNA gene sequence, and the DNA $\mathrm{G}+\mathrm{C}$ content were similar to those of other recognized Anoxybacillus species. The specific phenotypic properties and sequence similarities of less than $97 \%$ with the closest relatives indicated that strain $\mathrm{BT} 13^{\mathrm{T}}$ represents a novel species. Therefore we propose the name Anoxybacillus bogrovensis sp. nov. for the novel isolate.

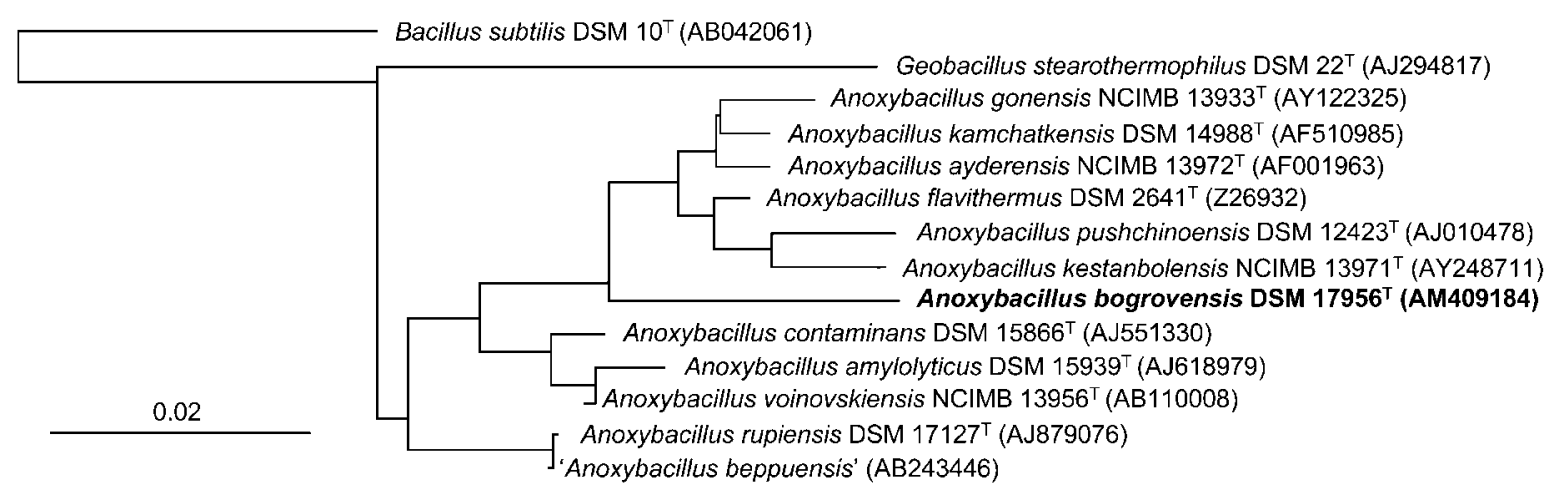

Fig. 2. Phylogenetic position of strain $B T 13^{\top}$ within the genus Anoxybacillus, based on $16 \mathrm{~S}$ rRNA gene sequence comparison. Geobacillus stearothermophilus was included as the type species for Geobacillus and Bacillus subtilis as the outgroup. Bar, 0.02 nucleotide substitutions per position. 


\section{Description of Anoxybacillus bogrovensis sp. nov.}

Anoxybacillus bogrovensis (bo.gro.ven'sis. N.L. masc. adj. bogrovensis, pertaining to Bogrov region, referring to the place of isolation of the type strain).

Cells are Gram-positive, rod-shaped, single or in long chains, facultatively anaerobic, non-motile and 1.4$4.0 \times 0.3-0.6 \mu \mathrm{m}$. Endospores are ellipsoidal, and located terminally in non-swollen sporangia. After cultivation for $24 \mathrm{~h}$ on PY agar, colonies are pale white-yellowish in colour, with an irregular edge, high conical surface and viscous consistency. Moderately thermophilic (temperature range for growth is $40-69{ }^{\circ} \mathrm{C}$, with optimum growth at $65{ }^{\circ} \mathrm{C}$ ) and alkalitolerant $(\mathrm{pH}$ range for growth is $6.0-10.0$, with an optimum at $\mathrm{pH} 8.0$ ). Doubling time is $28 \mathrm{~min}$. Catalase-positive and grows at $\mathrm{NaCl}$ concentrations up to $1.5 \%$, with optimum growth at $0.5 \%$. Chemo-organotrophic, and is able to ferment a wide spectrum of carbon sources: D-glucose, fructose, sucrose, maltose, cellobiose, Lrhamnose, L-arabinose, melibiose, amygdalin, mannitol, salicin, glycogen and starch. The Voges-Proskauer reaction is negative. Starch and gelatin are hydrolysed, but casein is not. Acetoin, $\mathrm{H}_{2} \mathrm{~S}$ and indole are not formed, phenylalanine and urea are not decomposed, and nitrates are not reduced. Arginine dihydrolase, lysine decarboxylase, ornithine decarboxylase and tryptophan deaminase tests are negative; $\beta$-galactosidase is positive. Cells mainly contain iso-branched saturated fatty acids (content of about $80 \%$ of the total fatty acids). The major fatty acid is iso- $\mathrm{C}_{15: 0}$, followed by iso- $\mathrm{C}_{17: 0}$ and anteiso- $\mathrm{C}_{17: 0}$. The $\mathrm{G}+\mathrm{C}$ content of the DNA of the type strain is $44.1 \mathrm{~mol} \%$.

The type strain, BT $13^{\mathrm{T}}\left(=\right.$ DSM $17956^{\mathrm{T}}=$ NBIMCC $\left.8427^{\mathrm{T}}\right)$, was isolated from a hot spring near Dolni Bogrov village, Sofia region, Bulgaria.

\section{Acknowledgements}

This research work was realized with the financial support of the NATO Reintegration Grant no. 981184 (2004).

\section{References}

Belduz, A. O., Dulger, S. \& Demirbag, Z. (2003). Anoxybacillus gonensis sp. nov., a moderately thermophilic, xylose-utilizing, endosporeforming bacterium. Int J Syst Evol Microbiol 53, 1315-1320.

Boone, D. R., Liu, Y., Zhao, Z. J., Balkwill, D. L., Drake, G. R., Stevens, T. O. \& Aldrich, H. C. (1995). Bacillus infernus sp. nov., an Fe(III)- and $\mathrm{Mn}(\mathrm{IV})$-reducing anaerobe from the deep terrestrial subsurface. Int $\mathrm{J}$ Syst Bacteriol 45, 441-448.
Derekova, A., Sjøholm, C., Mandeva, R. \& Kambourova, M. (2007). Anoxybacillus rupiensis sp. nov., a novel thermophilic bacterium isolated from Rupi basin (Bulgaria). Extremophiles 11, 577-583.

Dulger, S., Demirbag, Z. \& Belduz, A. O. (2004). Anoxybacillus ayderensis sp. nov. and Anoxybacillus kestanbolensis sp. nov. Int J Syst Evol Microbiol 54, 1499-1503.

Heinen, W., Lauwers, A. M. \& Mulders, J. W. M. (1982). Bacillus flavothermus, a newly isolated facultative thermophile. Antonie van Leeuwenhoek 48, 265-272.

Johansen, J. E., Nielsen, P. \& Sjøholm, C. (1999). Description of Cellulophaga baltica gen. nov., sp. nov. and Cellulophaga fucicola gen. nov., sp. nov. and reclassification of [Cytophaga] lytica to Cellulophaga lytica gen. nov., comb. nov. Int J Syst Bacteriol 49, 1231-1240.

Kevbrin, V. V., Zengler, K., Lysenko, A. M. \& Wiegel, J. (2005). Anoxybacillus kamchatkensis sp. nov., a novel thermophilic facultative aerobic bacterium with a broad $\mathrm{pH}$ optimum from the Geyser valley, Kamchatka. Extremophiles 9, 391-398.

Mesbah, M., Premachandran, U. \& Whitman, W. B. (1989). Precise measurement of the $\mathrm{G}+\mathrm{C}$ content of deoxyribonucleic acid by highperformance liquid chromatography. Int J Syst Bacteriol 39, 159-167.

Miller, G. L. (1959). Use of dinitrosalicylic acid reagent for determination of reducing sugar. Anal Chem 31, 426-428.

Pantschev, C., Klenz, G. \& Hafner, B. (1981). Vergleichende Charakterisierung von Alfa-Amylasepraparaten. Lebensmittelindustrie 28, 71-74 (in German).

Pikuta, E., Lysenko, A., Chuvilskaya, N., Mendrock, U., Hippe, H., Suzina, N., Nikitin, D., Osipov, G. \& Laurinavichius, K. (2000). Anoxybacillus pushchinensis gen. nov., sp. nov., a novel anaerobic, alkaliphilic, moderately thermophilic bacterium from manure, and description of Anoxybacillus flavithermus comb. nov. Int J Syst Evol Microbiol 50, 2109-2117.

Pikuta, E., Cleland, D. \& Tang, J. (2003). Aerobic growth of Anoxybacillus pushchinoensis $\mathrm{K}^{\mathrm{T}}$ : emended descriptions of $A$. pushchinoensis and the genus Anoxybacillus. Int J Syst Evol Microbiol 53, 1561-1562.

Poli, A., Esposito, E., Lama, L., Orlando, P., Nicolaus, G., de Appolonia, F., Gambacorta, A. \& Nicolaus, B. (2006). Anoxybacillus amylolyticus sp. nov., a thermophilic amylase producing bacterium from Mount Rittmann (Antarctica). Syst Appl Microbiol 29, 300307.

Smibert, R. M. \& Krieg, N. R. (1981). General characterization. In Manual of Methods for General Microbiology, pp. 409-443. Edited by P. Gerhardt, R. G. E. Murray, R. N. Costilow, E. W. Nester, W. A. Wood, N. R. Krieg \& G. B. Phillips. Washington, DC: American Society for Microbiology.

Stackebrandt, E. \& Goebel, B. M. (1994). Taxonomic note: a place for DNA-DNA reassociation and $16 \mathrm{~S}$ rRNA sequence analysis in the present species definition in bacteriology. Int $J$ Syst Bacteriol 44, 846-849.

Strunck, O. \& Ludwig, W. (1995). ARB - a software environment for sequence data, Department of Microbiology, University of Munich, Munich, Germany. Available at http://www.arb-home.de 